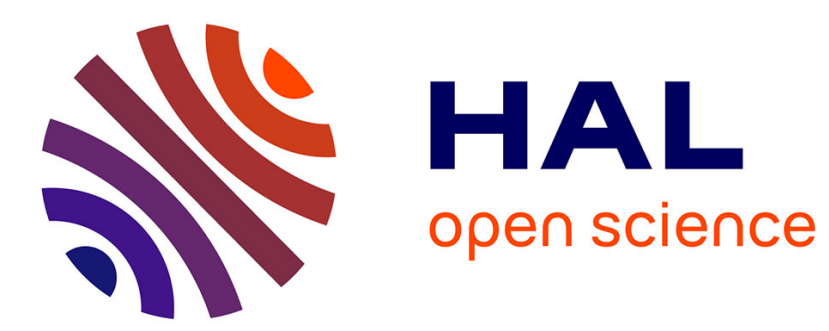

\title{
Effects of static and cyclic fatigue at high temperature upon reaction bonded silicon nitride
}

\author{
Michel Boussuge, Jacques Lamon
}

\section{To cite this version:}

Michel Boussuge, Jacques Lamon. Effects of static and cyclic fatigue at high temperature upon reaction bonded silicon nitride. Journal de Physique Colloques, 1986, 47 (C1), pp.C1-557-C1-562. 10.1051/jphyscol:1986184 . jpa-00225615

\section{HAL Id: jpa-00225615 https://hal.science/jpa-00225615}

Submitted on 1 Jan 1986

HAL is a multi-disciplinary open access archive for the deposit and dissemination of scientific research documents, whether they are published or not. The documents may come from teaching and research institutions in France or abroad, or from public or private research centers.
L'archive ouverte pluridisciplinaire HAL, est destinée au dépôt et à la diffusion de documents scientifiques de niveau recherche, publiés ou non, émanant des établissements d'enseignement et de recherche français ou étrangers, des laboratoires publics ou privés. 


\title{
EFFECTS OF STATIC AND CYCLIC FATIGUE AT HIGH TEMPERATURE UPON REACTION BONDED SILICON NITRIDE
}

\author{
M. BOUSSUGE and J. LAMON* \\ Centre des Matériaux, Ecole des Mines de Paris, B.P. 87 , \\ F-91003 Evry Cedex, France \\ "Battelle-Genève, 7, Route de Drize, $\mathrm{CH}-1227$ Carouge-Genève, \\ Switzerland
}

\begin{abstract}
Résumé - Les effets de la fatigue statique et de la fatigue cyclique à $\overline{1200^{\circ} \mathrm{C}}$ sur le nitrure de silicium fritté par réaction ont été évalués grâce à une approche statistique qui permet de caractériser la distribution des défauts microstructuraux responsables de la rupture. Fatigues statique et cyclique exercent des effets différents sur RBSN. L'évolution de la distribution des défauts microstucturaux est fortement dépendante de la fréquence. Les sollicitations cycliques à basse fréquence et les sollicitations statiques tendent à cicatriser les défauts de surface, tandis que la fatigue cyclique à haute fréquence affecte les défauts internes. Ces effets sont gouvernés par l'oxydation.
\end{abstract}

Abstract - The effects of static fatigue and cyclic fatigue upon Reaction Bonded Silicon Nitride (RBSN) were compared using the statistical distributions of residual strengths measured in tension. The strength-controlling flaws are highly dependent upon frequency. It was found that low frequency cyclic and short-term static loadings blunted surface flaws, whereas high frequency cyclic fatigue affects internal flaw populations. This situation is attributed to oxidation related mechanisms.

\section{I - INTRODUCTION}

Ceramic materials are now considered a viable alternative to metals in many structural applications at high temperature. However, there is an important delay in their use, in large part due to their poor reliability. A first step towards their successful use is obviously to select the material having the most suitable service life, which implies that the material response to such factors as environment, loading conditions and geometrical effects be properly characterized.

Static and dynamic fatigue of ceramics have been the subject of extensive studies. The methodology which was developed for life-time predictions emerged as a promising and successful technique, particularly with glass and alumina at room temperature in various environments and with such hot pressed ceramics as SiC or $\mathrm{Si}_{3} \mathrm{~N}_{4}$ at high temperature $/ 1 /$. Comparatively little is known about the behaviour of ceramics under cyclic loading conditions. But it has been frequently suggested that there is no enhanced effect of cycling on the crack propagation rate. Life-time predictions under cycling loading conditions are generally based upon the assumption that fracture results from the same phenomena as static fatigue. Thus, the crack growth rate or time-to-failure are predicted from the static slow crack growth parameters $/ 2,3 /$. Such approaches present evident limitations for materials where slow crack growth is not the predominant cause of damage. 
Experimental studies indicate that several commercial $\mathrm{Si}_{3} \mathrm{~N}_{4}$ and $\mathrm{SiC}$ ceramics are relatively inert to slow crack growth in oxidizing environments above $1000^{\circ} \mathrm{C} / 4-6 /$ and that oxidation related phenomena may cause an overall deterioration of specimens by affecting surface and internal defects /7-9/. Slow crack growth may also occur in combination with oxidation and apparently may take place by several mechanisms including grain-boundary separation through the creep of a viscous secondary phase $/ 10,11 /$.

The intent of the present paper is to compare the respective effects of static and cyclic loading conditions at high temperature in air upon Reaction Bonded Silicon Nitride, candidate for application in various systems (gas turbines, etc...). One approach to a greater understanding of the influence of fatigue is to characterize its effects upon the strength distributions. Analysis of these residual strength distributions using a statistical description of fracture permits the determination of the shape parameters which characterize the distribution of fracture inducing flaws. This paper reports on changes in the strength distributions of RBSN after high temperature static and cyclic fatigues at low and high frequencies. Fatigue data confirm that the slow growth of a unique crack is not necessarily a preponderant mechanism of damage at high temperature in ceramics.

\section{II - EXPERIMENTAL PROCEDURE}

The RBSN in this study is a commercial product (namely Rosinit) from Rosenthal AG. The principal properties are given in Table 1.

Tensile specimens were machined from $10 \mathrm{~mm}$ diameter rods. The dimensions of specimens are given in Figure 1. After machining, the gauge length of specimens was carefully polished using 320- and 600- grit SiC papers. Roughness of the finished surfaces was measured longitudinally and around the circumference. $R_{a}-v a l u e s$ between $0.25 \mu \mathrm{m}$ and $0.42 \mu \mathrm{m}$ were obtained.

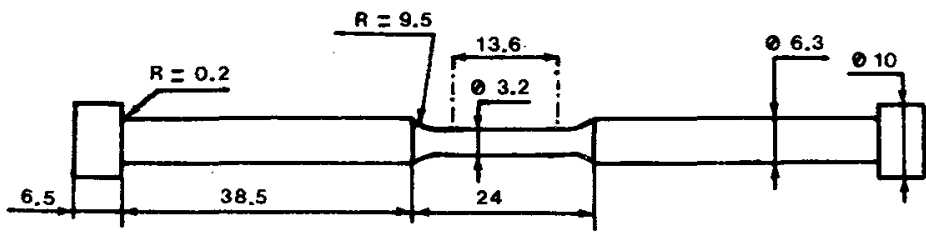

Fig. 1 - Dimensions of tensile specimens

According to the aim of this work (which was the evaluation of the damage caused to RBSN by static fatigue and cyclic loading conditions) it was imperative that no catastrophic failure occurred on fatigue tests. Therefore the testing conditions were selected to favor damage caused by time dependent processes. The specimens were first proof tested in tension at room temperature at a loading rate of $\simeq 1$ $\mathrm{MPa} / \mathrm{sec}$. The proof stress was the upper bound of the sinusoidal stress applied on fatigue tests (i.e. $70 \mathrm{MPa}$ ). The corresponding failure probability pertains to the lower end of the strength distribution $: P_{f} \simeq 0.2 \%$. It is worth noting that no specimen failed on proof-test.

Cyclic fatigue tests were performed at $1200^{\circ} \mathrm{C}$ in air, using an hydraulic testing machine (Instron 1331). Special care was taken in specimen alignment, which was achieved using rubber-cushioned, split grips where the shouldered ends of specimens were clamped. Specimens were heated in a small centre portion using high intensity lamps which focus on the gauge length. The temperature was controlled using a thermocouple around the specimen gauge. The lower and upper bounds of the sinusoidal stress applied on fatigue tests were respectively 35 and 70 MPa. Two frequencies were selected : $0.8 \mathrm{~Hz}$ and $80 \mathrm{~Hz}$. Test duration was limited to 7 hours. The residual strengths were measured in tension at room temperature, at a displacement rate of $1 \mathrm{~mm} / \mathrm{min}$.

For comparison, static fatigue tests were performed in similar conditions : at 
$1200^{\circ} \mathrm{C}$, in air for 7 hours. The applied stress was the average of the periodic stress applied on cyclic loading tests (i. e. $52.5 \mathrm{MPa}$ ). The residual strengths were measured as described above for cyclic fatigue specimens.

Additionnally, to check the existence of a time-dependent failure process, the time-to-failure was measured at $1200^{\circ} \mathrm{C}$ for 10 specimens which experienced various constant static loads.

The residual strengths were treated using the ranking statistics method where the strengths are ordered from lowest to highest and assigned a rank $i$ such that :

$$
P=\frac{i}{N+I}
$$

where $\mathrm{N}$ is the total number of specimens and $\mathrm{P}$ the failure probability. The strengths were analysed using the two parameter WeibulI solution, which is convenient for the determination of the shape parameter $m$ :

$$
P=1-\exp \left[-\int_{V}\left(\frac{S}{S}\right)^{m} d V\right]
$$

where $S_{0}$ is the scale factor, $S$ strength and $V$ specimen volume.

III - RESULTS AND DISCUSSION

a. Static fatigue time-to-failure data

Figure 2 shows that the time-to-failure data at $1200^{\circ} \mathrm{C}$ under various stresses are inversely dependent upon the applied stress. These results assess the existence of a time-dependent failure process.

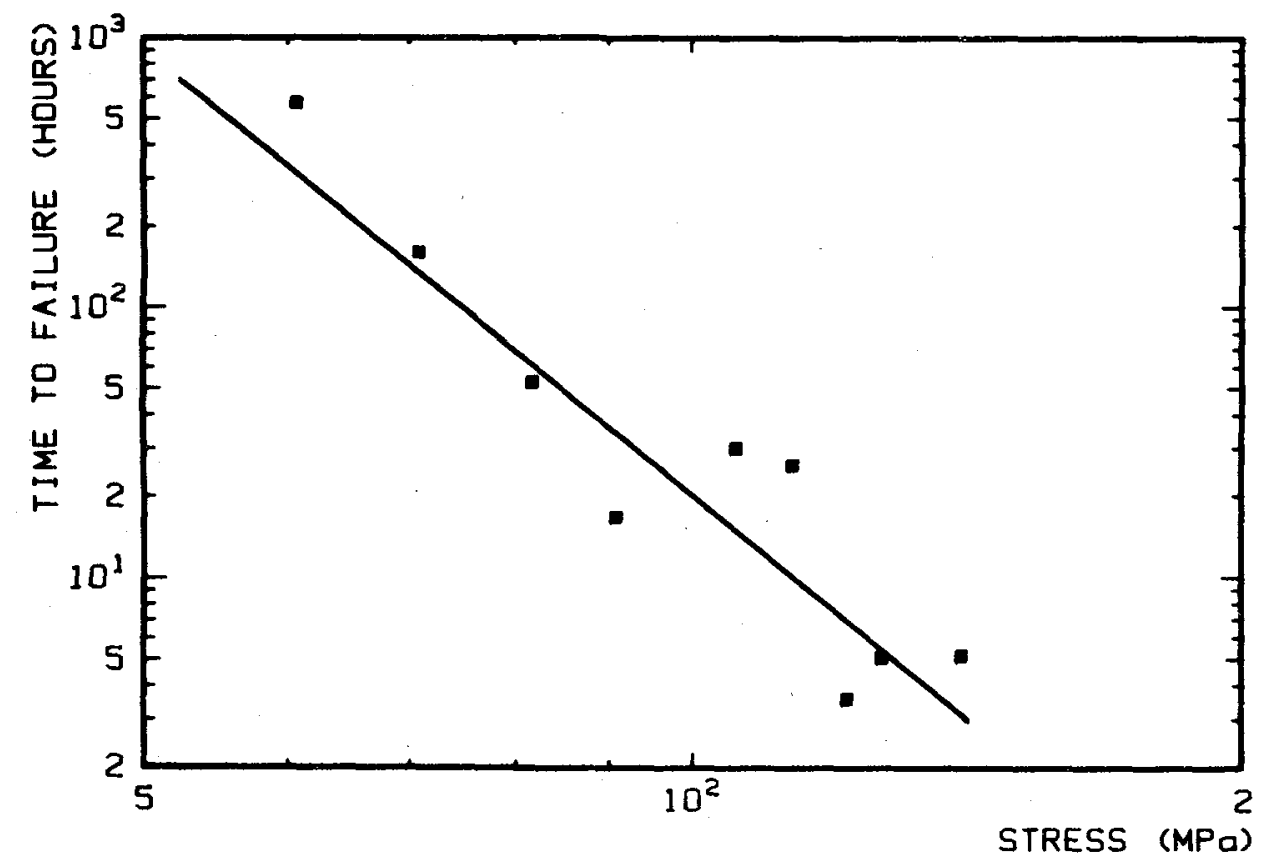

Fig. 2 - Time to failure of tensile specimens of RBSN under various constant stresses at $1200^{\circ} \mathrm{C}$ in air.

Although the mechanism involved has not been identified, data suggest that fracture of specimens is caused by a creep mechanism. Thus, linear regression analysis of the log-log plot of time-to-failure data shows that failure may be satisfactorily described by the following equation :

$$
t_{f} \sigma^{n}=\text { constant }
$$


where $t_{f}$ is the time-to-failure, $\sigma$ the applied stress and $\mathbf{n}$ a stress exponent ranging from 3 to 5 for most engineering materials. The correlation coefficient is rather high $\left(r^{2}=0.873\right)$ and the value obtained for $n$ is 5.5 . It is worth noting that other relations such as the equation used by Birch and co-workers /12/ for RBSN creep failure ( $t_{f} \exp B \sigma=$ constant (2)) could be applied. However the equation (2) fits less satisfactorily to the data than equation ( 1 ).

b. Static and cyclic fatigue tests

The effects of static and cyclic fatigue tests on the strength distribution of RBSN are shown in Figure 3. The distinctly separated strength distributions clearly indicate that there is a loss in the average strength after cyclic fatigue tests and an increase after static fatigue tests.

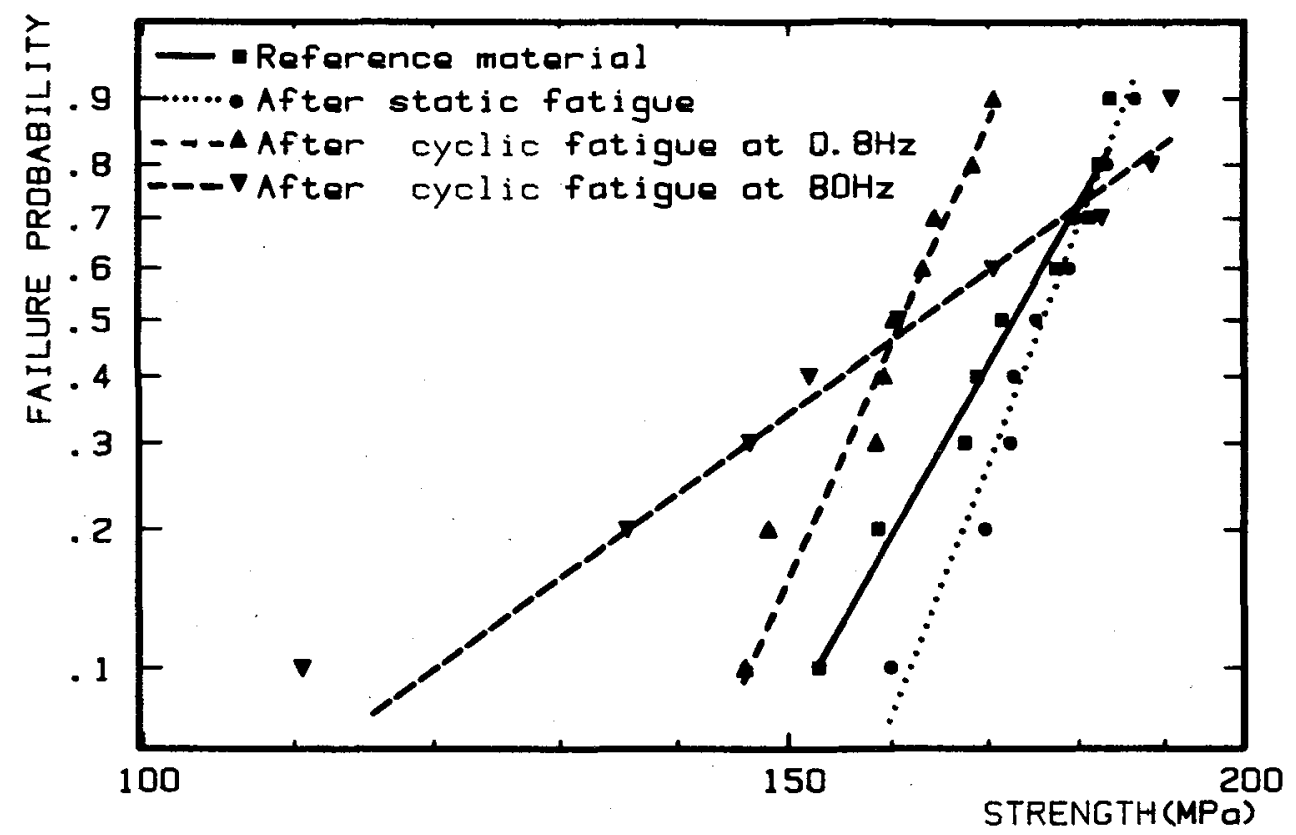

Fig. 3 - Strength distributions for tensile specimens of RBSN after static fatigue tests under the constant stress of $52 \mathrm{MPa}$ and cyclic fatigue tests at $0.8 \mathrm{~Hz}$ and 80 $\mathrm{Hz}$, at $1200^{\circ} \mathrm{C}$ for 7 hours in air

A log-log plot of the strength distributions suggests that single flaw populations dictated fracture for each set of specimens. Using a Weibull description of failure, the statistical parameters pertinent to each distrit_tion were obtained using an iterative least-squares curve fitting computer program. The average strengths and statistical parameters are given in Table 2.

\begin{tabular}{|c|c|}
\hline Bulk density / $/$ / & 2.42 \\
\hline Porosity /6/ & $25 \mathrm{w} / \mathrm{o}$ \\
\hline Young's modulus $/ 6 /$ & $160 \mathrm{GPa}$ \\
\hline $\begin{array}{l}\text { Fracture toughness } \\
\text { at R.T. } / 6 /\end{array}$ & $3 \mathrm{MF} a \mathrm{dm}$ \\
\hline Specific Heat & $0.85 \mathrm{~J} / \mathrm{g}^{\circ} \mathrm{K}$ \\
\hline Thermal conductivity & $0.17 \mathrm{~W} / \mathrm{cm}^{\circ} \mathrm{K}$ \\
\hline $\begin{array}{l}\text { Thermal expansion } \\
\text { coefficient }\end{array}$ & $2.910^{-6} / 0 \mathrm{~K}$ \\
\hline
\end{tabular}

Table 1 : Principal properties of RBSN 


\begin{tabular}{|l|c|c|c|c|}
\hline & $\begin{array}{c}\text { Weibuli } \\
\text { shape } \\
\text { frarameter } \\
\text { m }\end{array}$ & $\begin{array}{c}\text { Scale } \\
\text { factor } \\
\text { So }\end{array}$ & $\Sigma$ & $\begin{array}{c}\text { Average } \\
\text { strength } \\
\text { (MPa) }\end{array}$ \\
\hline Reference material & 15.3 & 99 & $2.26510^{-3}$ & 171 \\
\hline $\begin{array}{l}\text { After static } \\
\text { fatigue }\end{array}$ & 22.2 & 120 & $1.7710^{-3}$ & 175.3 \\
\hline $\begin{array}{l}\text { After cyclic } \\
\text { fatigue }(0.8 \mathrm{~Hz})\end{array}$ & 20 & 105 & $2.7410^{-3}$ & 159 \\
\hline $\begin{array}{l}\text { After cyclic } \\
\text { fatigue }(80 \mathrm{~Hz})\end{array}$ & 6.2 & 13 & $1.5010^{-3}$ & 160 \\
\hline
\end{tabular}

Table 2 : Statistical parameters for RBSN $(\Sigma$ is the value of the least-squares sum which measures the fitting accuracy of the analysis to data).

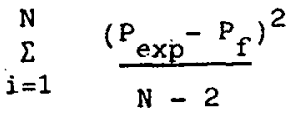

It is apparent from Table 2 that the shape parameter and the average strength increase after static fatigue. These results indicate that the distribution of fracture inducing flaws is more uniform in size and severity, and that their effectiveness as stress concentrators is decreased. This effect must be attributed to the oxide scale observed at the surface of specimens. The effect of cyclic loading upon the shape parameter is greatly dependent upon frequency. After low frequency tests, the shape parameter is close to obtained after static fatigue experiments, which indicates that low frequency fatigue has similar effects as static fatigue. After high frequency test, the shape parameter is comparable to the value pertinent to internal flaw population after long-term oxidation /7/, which reveals a significant change in the fracture source. This change may be attributed to internal oxidation which is enhanced by vibrations as demonstrated by Barlier et al. /13/.

High frequency loading conditions thus permit oxygen penetration and have similar effects as long-term oxidation on RBSN whereas low frequency loading conditions have similar influence as short-term oxidation. The latter primarily affects the surfin:t of specimens, whereas the former affects the internal defects of RBSN. However it is important to note that both low frequency and high frequency fatigues lead to material weakening.

\section{IV - CONCLUSIONS}

It has been demonstrated that static fatigue and cyclic fatigue may cause damage to RBSN by time dependent phenomena, and may exert different influences upon material properties.

Static fatigue at $1200^{\circ} \mathrm{C}$ under constant stress leads to fracture of specimens which must be attributed to creep rather than slow crack growth. Short-term static fatigue tends to strengthen specimens, by crack blunting due to superficial oxidation. Cyclic fatigue significantly degrades RBSN. This influence is greatly dependent upon the frequency. Thus high frequency loading enhances internal oxidation which enables fracture to initiate at the interior of specimens. Low frequency loading affects superficial defects and results in an increase of the shape parameter. The analysis of the strength distributions was thus successful in revealing subtle changes after static and cyclic fatigues of RBSN at $1200^{\circ} \mathrm{C}$. 


\section{REFERENCES}

/1/ Wiederhorn, S.M., Fracture Mechanics of Ceramics, 2, ed. Bradt, Hasselman, Lange, Plenum Press (1974), 613.

/2/ Matsuo, Y., Hattori, Y., Katayama, Y., Fukuura, I., Progress in Nitrogen Ceramics, ed. Riley, 65, (1983), 515.

/3/ Evans, A.G., Fuller, E.R., Met. Trans., 5, (1974), 27.

/4/ Becher, P.F., J. Amer. Ceram. Soc., 66, $\bar{n}^{\circ} 8$, (1983), C120.

/5/ Quinn, G.D., Ceram. Eng. Sci. Proc., 3 , n¹-2, (1982), 77.

/6/ Boussuge, M., Ph. D. Thesis, Ecole des Mines de Paris, 1985

/7/ Lamon, J., Boussuge, M., Science of Ceramics 12, ed. Vincenzini, (1983), 621.

/8/ Boussuge, M., Broussaud, D., Lamon, J., Proc. British Ceram. Soc., 32, (1982), 205.

/9/ Easler, T.E., Bradt, R.C., Tressler, R.E., J. Amer. Ceram. Soc., 65 , no 6, (1982), 317.

/10/ McHenry, K.D., Yonushonis, T., Tressler, R.E., J. Amer. Ceram. Soc., 58, n 5-6, (1976), 262

/11/ Evans, A.G., Wiederhorn, S.M., J. Mat. Science, 9, n², (1974), 270.

112/ Birch, J.M., Wilshire, B., Godfrey, D.J., Proc. British Ceram. Soc., 26, (1978), 141 .

/13/ Barlier, P., Torre, J.P., Ann. Chimie Sci. Mat., 5, n8, (1980), 701.

\section{ACKNOWLEDGEMENTS}

The authors wish to thank Turbomeca Company for specimen testing and DRET for support and for permission to publish this paper. 